INDO GLOBAL JOURNAL OF

PHARMACEUTICAL SCIENCES

ISSN 2249- 1023

\title{
Study of Biosynthesis \& Characterization of Microbial $\alpha$-Amylase by Using Banana Peel Waste
}

\author{
Neha Sharma ${ }^{1}$, Sarita Agrahari ${ }^{1 *}$, Neeraj Wadhwa ${ }^{2}$ \\ ${ }^{1}$ Department of Biotechnology, I.T.S. Paramedical College, Muradnagar, Ghaziabad, Uttar Pradesh, India \\ ${ }^{2}$ Department of Biotechnology, Jaypee Institute of Information Technology A-10, Sector-62, Noida-201 010, Uttar Pradesh, India
}

Address for Correspondence: Sarita Agrahari; hisarita@gmail.com

\begin{abstract}
Amylase is very essential for the conversion of starch into oligosaccharide. $\alpha$-Amylase (1,4-alpha-glucanglucanohydrolases) are extracellular enzymes which hydrolyze 1,4-glycosidic bonds and also are endoenzymes split the substrate in the interior of the molecule. Bacillus subtilis gave maximum production of alpha amylase as compared with the other strain. The study showed that the protein content and enzyme activity are high in different samples. Soil sample was collected from sugarcane waste dumping site, Muradnagar, Ghaziabad, India. Sample were inoculated in two different media using banana peel waste as an alternative source of carbon, which is an economic and profitable due to the inherent nature of the banana waste itself, for $\alpha$-amylase production by Bacillus subtilis as standard strain and by isolated culture from soil sample. The highest $\alpha$-amylase enzyme production and protein content were detected in media- II. we report that $\alpha$-amylase activity were detected in the crude sample of media II at pH 7 and temperature $35^{\circ} \mathrm{C}$ using maltose substrate. The isolated culture from soil sample shows high activity of $\alpha$-amylase enzyme as compared to Bacillus subtilis standard strain. The $\alpha$ amylase enzyme was used in the starch processing food, detergent, textile, paper, clinical and analytical industry. (C) 2014 iGlobal Research and Publishing Foundation. All rights reserved.
\end{abstract}

Conference Proceedings: International Conference on Life Sciences, Informatics, Food and Environment; August 29- 30, 2014

Indo Global Journal of Pharmaceutical Sciences( ISSN 22491023 ; CODEN- IGJPAI; NLM ID: 101610675) indexed and abstracted in EMBASE(Elsevier), SCIRUS(Elsevier),CABI, CAB Abstracts, Chemical Abstract Services(CAS), American Chemical Society(ACS), Index Copernicus, EBSCO, DOAJ, Google Scholar and many more. For further details, visit 